\title{
Effect of integrated pest management practices on tomato production and conservation of natural enemies
}

\author{
M. C. Picanço, L. Bacci, A. L. B. Crespo*, M. M. M. Miranda and Júlio C. Martins \\ Departamento de Biologia Animal, Universidade Federal de Viçosa, 36571-000 Viçosa, Minas Gerais State, Brazil and *Department of \\ Entomology, 202 Plant Industry Building, University of Nebraska Lincoln, 68503-0816 Lincoln, Nebraska, USA
}

\begin{abstract}
The present study used a crop life table to determine the critical components of production and the key factors of loss in tomato, and three treatments to identify the integrated pest management (IPM) benefits on the reduction of yield losses and the conservation of natural enemies.

2 The relative IPM benefits were compared using calendar-based pesticide applications, IPM and control (no pesticide). A total of 1248 tomato plants were allotted to treatments with four replicates of 104 plants, each in a random block design. The densities of vectors, leaf miners, fruit borers, predators and parasitoids were compared.

3 Fruit was the critical component of production, experiencing the greatest losses, followed by flower and plant in the vegetative phase. The key causes of loss of production were tospoviruses, Erwinia carotovora, Alternaria solani, Phytophthora infestans, Neoleucinodes elegantalis and blossom-end rot.

4 No significant differences in yield were detected between the calendar-based and IPM systems. In the control, the yield was lower than the yield in treatments with pesticides due to losses from fungal diseases and viruses. IPM more efficiently controlled pests than the calendar-system, reducing the number of parathionmethyl and abamectin applications by 3.8- and 2.9-fold, respectively. IPM treatment significantly reduced the impact of pesticides on natural enemies.

5 Tomato yield was more affected by biotic and abiotic factors during the reproductive stage. Because fruit was the production component most susceptible to loss, cultivation and IPM programmess should prioritize practices to reduce loss of this component.
\end{abstract}

Keywords Action thresholds, crop life table, crop management, parasitoids, pesticides, predators, Lycopersicon esculentum.

\section{Introduction}

Tomato Lycopersicon esculentum Mill, is a vegetable crop of large importance throughout the world. Its annual production accounts for 107 million metric tons, with fresh market tomatoes constituting $72 \%$ of this total (FAO, 2002). The susceptibility of tomato plants to insects and pathogens can be high, depending upon the pest species, crop stage, growing season and crop location (Picanço \& Marquini, 1999). This, coupled

Correspondence: M. C. Picanço, Departamento de Biologia Animal, Universidade Federal de Viçosa, Viçosa, MG 36571-000, Brazil. Tel.: +55 31 38992529; fax: +55 31 38992537; e-mail: picanco@ufv.br with factors such as high investment and fruit quality standards, has lead to a high number of pesticide applications, further increasing production costs (Guedes et al., 1994; Leite et al., 1995; Picanço et al., 1995). In addition to economic challenges, the conventional pest control system has other consequences, such as deleterious effects on the environment (Picanço et al., 2001).

An alternative to conventional pest control is the adoption of integrated pest management (IPM), in which a phytophagous organism is considered as a pest only when it reaches an economic threshold. The goals of the IPM system are to preserve and increase the natural mortality factors of pests by combining various pest management control practices in a 
compatible manner. The selection of these practices is based on technical, economical, ecological and social parameters (Dent, 2000; Pedigo, 2002). When IPM was used, Imenes et al. (1992) observed insecticide application reductions of up to $93.4 \%$ without damage to tomato yields and a significant increase in the number of species of natural enemies was obtained. Sikora et al. (2002) also observed a reduction of U\$134.32 per ha in the production costs with IPM in tomatoes compared with conventional pest control.

To develop IPM, it is necessary to assess the relative importance of factors accounting for production losses. Crop life tables can be used to identify and quantify these losses, including the pests and pathogens that occur at different crop stages (Chandler, 1984; Della Lucia et al., 1984; Calil et al., 1985; Barrigossi et al., 1988; Costa et al., 1993).

Therefore, the present study aimed to determine and assess the critical component of production and the key factors of loss in the tomato, and the IPM benefits on the reduction of production losses and the preservation of natural enemies.

\section{Materials and methods}

\section{Study site and treatments}

The present study was carried out from 30 January to 22 May 1996, in the Zona da Mata region of Viçosa County $\left(20^{\circ} 48^{\prime} 45^{\prime \prime} \mathrm{S}, 42^{\circ} 56^{\prime} 15^{\prime \prime} \mathrm{W}\right)$, State of Minas Gerais, Brazil. The field plots were surrounded by grass pastures. The Zona da Mata region also produces significant acreages of maize, beans and several vegetables (cucumber, eggplant, green pepper, kale crops, okra, ornamentals and tomato). The soil type of the area is Podzólico Vermelho-Amarelo Distrófico fase Terraço, according to the Brazilian Classification (Resende et al., 1988), similar to the paleudult of the American Classification (USDA, 1975). The tomato variety cultivated was Santa Clara, and the treatments were calendar-based pesticide applications (two weekly fungicide and insecticide applications), IPM [insecticide applications by monitoring with economic thresholds (ETs) for tomato pests] and control (no pesticide applications). Pesticide sprays were applied using manual knapsack sprayers (Costal Manual PJH; Jacto, Brazil) equipped with hollow cone hydraulic nozzles (JD 14-2) at high volume (300-500 1/ha) and a pressure of 3 bar. Each IPM plot was scouted for pests weekly, and insecticide applications were designated for plots with insect populations at or above the ETs as: one insect-vector per plant, $20 \%$ of mined leaves and $5 \%$ of damaged fruits (Miranda et al., 1998; Paula et al., 1998). The pesticides used were the fungicides chlorothalonil $750 \mathrm{~g} / \mathrm{kg} \mathrm{WP}$ (1350 g AI/ha) and maneb $640 \mathrm{~g} / \mathrm{kg}$ WP (1120 g AI/ha) (for Phytophthora infestans control), and the insecticides parathion-methyl $600 \mathrm{~g} / \mathrm{lEC}$ (252 g AI/ha) (for thrips control), abamectin $18 \mathrm{~g} / \mathrm{lEC}$ (18 g AI/ha) (for control of leafminers and fruit borers) and pirimicarb $500 \mathrm{~g} / \mathrm{kg} \mathrm{WP}$ (250 g AI/ha) (for aphid control) (Guedes et al., 1994). The scouting for pests and the calendarbased pesticide applications were stopped in plots where all plants had exhausted the potential to produce marketable fruits.

\section{Experimental design}

The experiment was set up in a random block design with four replicates. Each plot had eight rows containing 13 plants. The plants were spaced $0.5 \mathrm{~m}$ within rows and $1.0 \mathrm{~m}$ between rows. Plots were separated $2.0 \mathrm{~m}$ apart and blocks were separated by $4.0 \mathrm{~m}$. The data were collected for 24 plants in the six inner rows in each plot. All tomato plants were pruned to grow as two-stemmed plants, and regular cultural practices were used (Filgueira, 2003).

\section{Crop life table}

Plant mortality and its causes were evaluated weekly from the beginning of the vegetative stage until the end of the reproductive stage. Plants were considered dead when they lost the potential to produce marketable fruits. Plants showing exaggerated symptoms of drought were removed entirely from the experimental unit. The roots were placed in plastic bags, washed and examined to identify the causal agent. The plants killed by diseases were removed to isolate and identify the causal agent, whenever possible. Because tomato plants have flowers and fruits coexisting in the reproductive stage, three production components were studied at the reproductive stage: plant, flower and fruit. At the end of the crop period, the number of flowers and fruits per plant were recorded (Picanço et al., 1997, 1998).

Female flowers were marked and the number of aborted flowers recorded daily.

The fruits were marked and the number of fruits lost by different causes were recorded daily. The insects observed attacking the fruits were identified. Tomatoes were harvested weekly after the first cluster produced mature green and red-ripe tomatoes. Fruits with symptoms of disease were individually wrapped in dry paper for diagnosis. At harvest, fruits were collected, then counted, weighed and graded as marketable or nonmarketable (fruits with damage or less than $52 \mathrm{~mm}$ in diameter).

The losses in the crop yield components were estimated in each replicate using the equations developed by Picanço (1992), as reported below.

The potential crop yield was estimated in the beginning of the vegetative phase using the equation: $P d P l=P l \times F l$ I $P L \times W f r \times F$, where: $P d P l=$ yield estimate at the beginning of the cultivation $(\mathrm{kg} / \mathrm{ha}), P l=$ number of live plants in each replicate at the beginning of the cultivation, $F l / P L=$ total number of flowers per plant, $W f r=$ average weight of fruits $(\mathrm{kg})$, and $F=$ conversion factor for the yield from the area of each replicate to 1 ha.

The losses by each plant mortality factor in the plant vegetative phase were estimated using the equation: $L s P l_{\mathrm{i}}=P l L s_{\mathrm{i}} \times F l / P L \times W f r \times F$, where: $L s P l_{\mathrm{i}}=$ estimated loss by each mortality factor $(i), P l L s_{\mathrm{i}}=$ number of plants killed by each factor, and $i=$ plant mortality factor [tomato mosaic virus (ToMV), tomato yellow top virus (ToYTV), Meloidogyne spp., P.infestans, Tospovirus and Ralstonia solanacearum]. The remaining components of this and other equations (i.e. $W f r$ and $F$ ) are as previously described.

The production of flowers as a yield component was estimated using the equation: $P d F l=P l h \times F l / P L \times W f r \times F$, 
where: $P d F l=$ yield estimate based on flower as yield component $(\mathrm{kg} / \mathrm{ha})$, and $P l h=$ number of plants in each replicate at the harvest.

The losses by flower abortion were estimated using the equation: $L s F l A b=F l A b \times W f r \times F$, where: $L s F l A b=$ estimate of loss by flower abortion in each replicate $(\mathrm{kg} / \mathrm{ha})$, and $F l A b=$ number of female flowers aborted.

The fruit yield was estimated using the equation: $P d T F r=P l h \times F r t / P L \times W f r \times F$, where: $P d T F r=$ estimate of total fruit yield $(\mathrm{kg} / \mathrm{ha}), F r t / P L=$ average number of total fruits per plant.

The fruit loss was estimated using the equation: $L s F r_{\mathrm{i}}=F r L s_{\mathrm{i}} \times W f r \times F$, where: $L s F r_{\mathrm{i}}=$ loss of fruits by each factor $(i), F r L s_{\mathrm{i}}=$ number of fruits lost in each replicate due to each factor $(i), i=$ factor of fruit loss [Neoleucinodes elegantalis, Tospovirus, Spodoptera eridania, Alternaria solani, blossom-end rot (BER), Tuta absoluta, nonmarketable size, Erwinia carotovora, cracked, P. infestans, Picthia picthia and other causes].

The yield of marketable fruits was estimated by the equation: $P d M k F r=P l h \times F r M k / P L \times W f r \times F$, where: $P d T F r=$ yield estimate of marketable fruits (kg/ha), FrMk/ $P L=$ average number of marketable fruits harvested per plant.

\section{Arthropod sampling}

Samplings were performed twice a week on ten plants in the central area of each plot. Insect vectors, predators and parasitoids were sampled by beating the plant apex against a white plastic tray (Miranda et al., 1998). Leaf miners were sampled by evaluating the presence of mines on the third leaf from the plant apex. The percentage of stem apexes presenting perforations was also evaluated. The percentage of bored fruits was evaluated in the youngest cluster of the plant (Imenes et al., 1992; Miranda et al., 1998).

\section{Statistical analysis}

Crop life table. Tables of crop losses were developed for each replicate with the following components: yield component (plants, flowers, total fruits and marketable fruits), estimated yield $(\mathrm{kg} / \mathrm{ha})$, causal factor of yield loss, yield loss $(\mathrm{kg} / \mathrm{ha})$, noncumulative losses (\%) and cumulative losses (\%). The noncumulative losses $(100 \mathrm{ncl})$ were calculated using the equation: $100 \mathrm{ncl}=\left(L s_{\mathrm{i}} / P d_{\mathrm{i}}\right) \times 100$, where: $L s_{\mathrm{i}}=1$ loss estimated by each factor $(i)$ for the yield components, and $P d_{\mathrm{i}}=$ yield estimate $(\mathrm{kg} / \mathrm{ha})$ in each yield component. The accumulative losses $(100 \mathrm{cl})$ were calculated using the equation: $100 \mathrm{cl}=\left(L s_{\mathrm{i}} / P d P l\right) \times 100$.

The critical components of yield loss were analysed by calculating the partial loss factors $\left(k_{\mathrm{i}}\right)$ of each critical component and the total loss factor $(K)$ using the equations: $k_{\mathrm{i}}=\log \left(P d_{\mathrm{i}}\right)-\log \left(P d_{\mathrm{i}+1}\right)$ and $K=\left(\Sigma k_{\mathrm{i}}\right)$, where: $i=$ yield component (plants, flowers, total fruits and marketable fruits), $P d_{\mathrm{i}}=$ yield estimate $(\mathrm{kg} / \mathrm{ha})$ for each yield component, and $P d_{\mathrm{i}+1}=$ yield estimate $(\mathrm{kg} / \mathrm{ha})$ for the subsequent component (Morris, 1963; Leite et al., 1996; Picanço et al., 1997, 1998).
The total loss factor $(K)$ was subjected to linear regression analysis using the curve-fitting procedure of SIGMAPLOT (SPSS, 2000) against each of the partial loss factors $\left(k_{i} s\right)$ as dependent variables. The partial loss factor with the steepest slope (slope of the confidence interval significantly different from the others at $P<0.05)$ was recognized as the critical component of yield loss (Podoler \& Rogers, 1975).

A similar strategy was also used to identify the key factor of loss within the critical component of production. The key factors of yield loss were recognized subjecting the partial loss factors $\left(k_{\mathrm{i}}\right)$ to regression analyses against the total loss factor $(K)$. The partial loss factors $\left(k_{\mathrm{i}}\right)$ and the total loss factor $(K)$ were estimated using the equations: $k_{\mathrm{i}}=\log \left(P d_{\mathrm{x}}\right)-$ $\log \left[\left(P d_{\mathrm{x}}-L s_{\mathrm{i}}\right)\right]$, where: $i=$ factor of loss for the critical yield component, $P d_{\mathrm{x}}=$ yield estimate $(\mathrm{kg} / \mathrm{ha})$ for the critical yield component, and $L s_{\mathrm{i}}=$ loss estimate for each factor $(i)$ for the critical yield component (Morris, 1963; Leite et al., 1996; Picanço et al., 1997, 1998). The partial key-factor of loss with the steepest slope (slope of the confidence interval significantly different from the others at $P<0.05$ ) was recognized as the main key-factor of yield loss (Podoler \& Rogers, 1975).

Arthropods. Correlation analyses were carried out separately both for predator densities and parasitoid densities between the pest species densities. Correlations were also carried out between the insect-vectors densities and viruses incidence on fruits. Similar analyses were performed for percentage of bored fruits and bacterial disease incidence. Fruit characteristics, insect-vector, predator and parasitoid densities, in relation to the three treatments both in the vegetative stage and in the reproductive stage, were subjected to the analyses of variance (ANOvA) and compared by the ScottKnott multiple range test. Those analyses were carried out using SAEG (Ribeiro Júnior, 2001).

\section{Results}

\section{Critical component of production}

The fruit mean yield averaged over the three treatments was $44.40 \pm 15.12$ ton/ha. Among the production components, the fruit was the production component with the heaviest losses ( $30.95 \pm 1.01$ ton/ha), followed by flower $(26.16 \pm 1.12$ ton/ ha) and plant (5.20 \pm 2.05 ton/ha). During the crop period, the total accumulated yield losses reached $58.39 \%$, and the tomato plants produced only $41.61 \%$ of their potential yield (106.72 \pm 12.25 ton/ha) (Table 1). The partial loss curve for the fruit component had the steepest slope $(b=0.72)$ (Fig. 1). For this reason, the most critical component of production was the fruit.

Viral diseases were caused by ToYTV $1.01 \%$, ToMV $1.32 \%$ and the tospovirus group $(0.45 \%)$. Fungal disease was caused by $P$. infestans (Mont.) (0.82\%). Bacterial disease was caused by $R$. solanacearum (Smith) (0.33\%). Nematodes causing plant mortality were Meloidogyne spp. (0.94\%). In the flower component, losses were due to flower drop (Table 1). 
Table 1 Crop life table for tomato Lycopersicon esculentum plants

\begin{tabular}{|c|c|c|c|c|c|}
\hline Yield component & $\begin{array}{l}\text { Estimated } \\
\text { yield }^{a}\end{array}$ & $\begin{array}{l}\text { Causal factor of } \\
\text { yield loss }\end{array}$ & Yield loss ${ }^{a}$ & $\begin{array}{l}\text { Non-cumulative } \\
\text { losses }\end{array}$ & $\begin{array}{l}\text { Cumulative } \\
\text { losses }\end{array}$ \\
\hline \multirow[t]{7}{*}{ Plants } & \multirow[t]{7}{*}{106716.14} & ToMV & 1410.00 & 1.32 & 1.32 \\
\hline & & ToYTV & 1080.32 & 1.01 & 1.01 \\
\hline & & Meloidogyne spp. & 1004.10 & 0.94 & 0.94 \\
\hline & & Phytophthora infestans & 879.31 & 0.82 & 0.82 \\
\hline & & Tospovirus & 475.18 & 0.45 & 0.45 \\
\hline & & Ralstonia solanacearum & 350.56 & 0.33 & 0.33 \\
\hline & & & 5199.47 & 4.87 & 4.87 \\
\hline \multirow[t]{2}{*}{ Flowers } & \multirow[t]{2}{*}{101516.67} & \multirow[t]{2}{*}{ Abortion } & 26163.33 & 25.77 & 24.52 \\
\hline & & & 26163.33 & 25.77 & 29.39 \\
\hline \multirow{13}{*}{ Total fruits } & \multirow[t]{13}{*}{75353.34} & Neoleucinodes elegantalis & 11706.79 & 15.54 & 10.97 \\
\hline & & Tospovirus & 3758.12 & 4.99 & 3.52 \\
\hline & & Spodoptera eridania & 3412.19 & 4.53 & 3.20 \\
\hline & & Alternaria solani & 3302.12 & 4.38 & 3.09 \\
\hline & & Blossom-end rot & 1941.96 & 2.58 & 1.82 \\
\hline & & Tuta absoluta & 1926.23 & 2.56 & 1.81 \\
\hline & & Non-marketable size & 1571.35 & 2.09 & 1.47 \\
\hline & & Erwinia carotovora & 1446.64 & 1.92 & 1.36 \\
\hline & & Cracked & 1100.71 & 1.46 & 1.03 \\
\hline & & Phytophthora infestans & 684.01 & 0.91 & 0.64 \\
\hline & & Picthia picthia & 62.90 & 0.08 & 0.06 \\
\hline & & Other causes & 39.31 & 0.05 & 0.04 \\
\hline & & & 30952.31 & 41.08 & 58.39 \\
\hline Marketable fruits & 44401.03 & & 62315.11 & & 58.39 \\
\hline
\end{tabular}

akg of fruits/ha.

Data represent the average of the three different treatments in Viçosa County, State of Minas Gerais, Brazil, 1996.

ToMV, Tomato mosaic virus; ToYTV, tomato yellow top virus.

\section{Key factor of loss}

Once we had identified fruit as the critical production component, we compared the regression coefficients for fruit losses caused by each loss factor. The partial loss curves of fruits for tospovirus group $(b=0.24)$, bacterium E. carotovora (Jones) $(b=0.16)$, fungi A. solani (Ellis \& Martin) $(b=0.15)$ and $P$. infestans $(b=0.14)$, tomato fruit borer

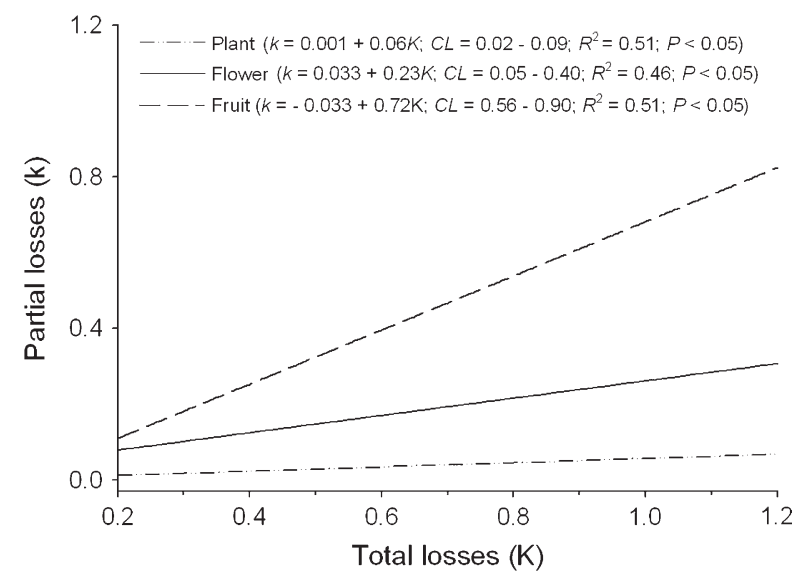

Figure 1 Partial loss curves ( $k$ ) of plants during vegetative stage, flowers, and fruits as function of total losses during the tomato Lycopersicon esculentum crop period $(K)$ cultivated under the three treatments.
N. elegantalis (Guenée) (Lepidoptera: Crambidae) $(b=0.11)$ and BER $(b=0.09)$ had the steeper slopes (Table 2). For this reason, they were the key factors of losses.

The incidence of the tospoviruses in fruits had a positive correlation with the density of the thrips Frankliniella schultzei (Trybom) (Thysanoptera: Thripidae) on plants during the reproductive stage $(r=0.99, P<0.001)$. These viruses are transmitted by this thrips (Fajardo et al., 2000). Correlations were detected among the percentages of damaged fruits by bacterium E. carotovora and percentages of bored fruits for $S$. eridania (Cramer) $(r=0.60$ and $P=0.0201)$ and $N$. elegantalis $(r=0.57$ and $P=0.0255)$.

\section{IPM effects on tomato production, pests and natural enemies}

Higher yields were obtained in the calendar-based and IPM crop production systems, with $55.05 \pm 3.91$ and $61.21 \pm 4.23$ ton/ha, respectively. In the calendar-based and IPM systems, the fruit mean weight was greater than that obtained in the control. In the control, the yield was only $13.82 \pm 4.96$ ton/ha because of the losses due to fungal diseases, caused by A. solani and $P$. infestans, and viruses caused by the tospovirus group transmitted by thrips (Cho et al., 1987; Resende \& Cupertino, 1996; Fajardo et al., 2000), and the tomato yellow top virus and transmitted by aphids (Resende \& Cupertino, 1996; Fajardo et al., 2000). The percentages of damaged fruits for $S$. eridania and $N$. elegantalis and the percentages of fruits attacked by viruses and $P$. infestans in the calendar-based and IPM system were 
Table 2 Regression equations, angular coefficient confidence intervals at $95 \%$ level $(95 \% \mathrm{Cl})$, determination coefficients $\left(r^{2}\right)$, and probability $(P)$ of the partial losses of fruit production $\left(K_{\mathrm{fr}}\right)$ as function of the total fruit losses $\left(K_{\mathrm{fr}}\right)$

\begin{tabular}{|c|c|c|c|c|}
\hline Causative factor ${ }^{a}$ & Equations & $95 \% \mathrm{Cl}$ & $r^{2}$ & $P$ \\
\hline Tuta absoluta & $k_{\mathrm{fr}}=0.017-0.02^{*} K_{\mathrm{fr}}$ & $-0.048-0.005$ & 0.25 & 0.030 \\
\hline Neoleucinodes elegantalis & $k_{\mathrm{fr}}=0.055+0.11^{* 11} K_{\mathrm{fr}}$ & $0.034-0.188$ & 0.51 & 0.012 \\
\hline Spodoptera eridania & $k_{\mathrm{fr}}=-0.003+0.10^{*} K_{\mathrm{fr}}$ & $0.076-0.121$ & 0.91 & $<0.001$ \\
\hline Phthia picta & $k_{\mathrm{fr}}=0.001-0.002^{*} K_{\mathrm{fr}}$ & $-0.005-0.002$ & 0.12 & 0.038 \\
\hline Alternaria solani & $k_{\mathrm{fr}}=-0.010+0.15^{*} K_{\mathrm{fr}}$ & $0.085-0.212$ & 0.73 & 0.006 \\
\hline Phytophthora infestans & $k_{\mathrm{fr}}=-0.026+0.14^{*} K_{\mathrm{fr}}^{\prime \prime}$ & $0.102-0.187$ & 0.85 & 0.001 \\
\hline Erwinia carotovora & $k_{\mathrm{fr}}=-0.024+0.16^{*} K_{\mathrm{fr}}^{\prime \prime}$ & $0.085-0.240$ & 0.69 & 0.009 \\
\hline Tospovirus & $k_{\mathrm{fr}}=-0.021+0.24^{*} K_{\mathrm{fr}}$ & $0.136-0.337$ & 0.73 & 0.005 \\
\hline Blossom-end rot & $k_{\mathrm{fr}}=-0.003+0.09^{*} K_{\mathrm{fr}}$ & $0.027-0.144$ & 0.51 & 0.011 \\
\hline Non-marketable size & $k_{\mathrm{fr}}=0.008+0.01^{*} K_{\mathrm{fr}}$ & $-0.012-0.025$ & 0.06 & 0.042 \\
\hline Cracking & $k_{\mathrm{fr}}^{\prime}=0.003+0.03^{*} K_{\mathrm{fr}}^{\prime \prime}$ & $-0.002-0.065$ & 0.30 & 0.021 \\
\hline
\end{tabular}

aThere were 12 replicates for each causative factor.

smaller than in the control. The other fruit characteristics were similar among the three control systems. IPM was more efficient at controlling pests than was the calendar-system and proved to be effective at reducing the number of parathion-methyl and abamectin applications by 3.8- and 2.9-fold, respectively (Table 3).

During the reproductive stage of the crop, the largest total and adult densities of $F$. schultzei on plants were observed in the control. Similarly, during the vegetative stage, the largest adult densities of Bemisia tabaci (Gennadius) on plants were seen in the control. Also during the vegetative stage, the largest total and adult densities of F. schultzei on plants were observed in the control and, conversely, the lowest densities in the calendar-based system. By contrast, the largest total and wingless aphids densities of Macrosiphum euphorbiae (Thomas) and Myzus persicae (Sulzer) during the reproductive stage were seen in the calendar-based system. Likewise, during the same stage, the largest winged aphid densities of $M$. persicae on plants also occurred in the calendar-based system (Table 4). The densities of aphids M. persicae $(r=-0.99$, $P<0.001)$ and $M$. euphorbiae $(r=-0.99, P<0.001)$ were negatively correlated with Coccinellidae adults.
The most abundant predators present were: Araneida: Araneidae, Hymenoptera: Formicidae, Coleoptera: Staphylinidae, Carabidae, Coccinellidae (mainly Cycloneda sanguinea L.) Anthicidae (Anthicus sp.), Heteroptera: Anthocoridae (Xylocoris sp. and Orius sp.) and Thysanoptera: Phlaeothripidae. The most abundant parasitoids identified were the Goniozus nigrifemur Asmead (Bethylidae), Trichogramma pretiosum Riley (Trichogrammatidae), Bracon sp. and Chelonus sp. (Braconidae), and Chalcididae (Table 5).

During the vegetative stage of the crop, the calendar-based system decreased the populations of the predators Araneidae and Anthicidae. However, the IPM system enhanced the preservation of natural enemy populations due to the reduced number of insecticide applications in this stage (Table 5).

The predator populations of Araneidae, Formicidae, Anthicidae and Phaleothripidae in the control were higher than in the other treatments (calendar-based and IPM). The calendar-based system reduced the populations of Trichogrammatidae. A positive and significant correlation was observed between the populations of Bethylidae and T. absoluta $(r=0.06 ; P=0.0001)$, which is host of these

Table 3 Number of insecticide applications, yields and causes of fruit losses as function of the three treatments

\begin{tabular}{|c|c|c|c|c|c|c|}
\hline \multirow[b]{2}{*}{ Characteristic } & \multirow[b]{2}{*}{$n$} & \multicolumn{3}{|c|}{ Treatments (mean \pm SE) } & \multicolumn{2}{|l|}{ ANOVA } \\
\hline & & Calendar-based & IPM & Control & $F$ & $P$ \\
\hline Number of pirimicarb applications & 12 & $1.00 \pm 0.00^{\mathrm{a}}$ & $0.75 \pm 0.25^{a}$ & $0.00 \pm 0.00^{b}$ & $F_{2,9}=13.00$ & 0.002 \\
\hline Number of parathion-methyl applications & 12 & $15.25 \pm 0.85^{\mathrm{a}}$ & $4.00 \pm 0.91^{b}$ & $0.00 \pm 0.00^{c}$ & $F_{2,9}=120.04$ & $<0.001$ \\
\hline Number of abamectin applications & 12 & $16.00 \pm 0.91^{\mathrm{a}}$ & $5.50 \pm 0.65^{b}$ & $0.00 \pm 0.00^{c}$ & $F_{2,9}^{2,9}=158.60$ & $<0.001$ \\
\hline Number of total applications & 12 & $32.25 \pm 1.65^{a}$ & $10.25 \pm 0.25^{b}$ & $0.00 \pm 0.00^{c}$ & $F_{2,9}^{2,9}=291.78$ & $<0.001$ \\
\hline Medium weight of fruits (g) & 24 & $109.28 \pm 9.12^{\mathrm{a}}$ & $113.69 \pm 7.56^{\mathrm{a}}$ & $89.33 \pm 4.66^{b}$ & $F_{2,21}=3.12$ & 0.065 \\
\hline Yield (ton/ha) & 24 & $55.05 \pm 4.30^{\mathrm{a}}$ & $61.21 \pm 4.10^{\mathrm{a}}$ & $13.82 \pm 0.70^{b}$ & $=55.69$ & $<0.001$ \\
\hline Fruits damaged by Spodoptera eridania (\%) & 12 & $3.35 \pm 0.63^{b}$ & $3.72 \pm 0.85^{b}$ & $10.62 \pm 1.52^{\mathrm{a}}$ & $=14.87$ & 0.001 \\
\hline $\begin{array}{l}\text { Fruits damaged by Neoleucinodes } \\
\text { elegantalis (\%) }\end{array}$ & 12 & $13.93 \pm 0.42^{b}$ & $14.08 \pm 1.04^{b}$ & $21.24 \pm 0.47^{a}$ & $F_{2,9}=35.70$ & $<0.001$ \\
\hline Fruits attacked by Alternaria solani (\%) & 12 & $3.71 \pm 0.73^{a}$ & $5.02 \pm 1.07^{a}$ & $7.03 \pm 0.82^{a}$ & $F_{2,9}=3.55$ & 0.073 \\
\hline Fruits with viruses $(\%)$ & 12 & $4.19 \pm 1.15^{\mathrm{b}}$ & $3.01 \pm 0.70^{\mathrm{b}}$ & $12.53 \pm 3.21^{\mathrm{a}}$ & $F_{2,9}^{2,9}=6.67$ & 0.017 \\
\hline Fruits with blossom-end rot (\%) & 12 & $3.52 \pm 0.86^{a}$ & $2.46 \pm 0.66^{a}$ & $2.78 \pm 0.88^{a}$ & $F_{2,9}^{2,9}=0.46$ & $>0.500$ \\
\hline Fruits with bacterial diseases (\%) & 12 & $1.84 \pm 0.82^{\mathrm{a}}$ & $1.75 \pm 0.75^{\mathrm{a}}$ & $3.98 \pm 1.88^{\mathrm{a}}$ & $F_{2,9}^{2,9}=1.00$ & 0.405 \\
\hline Fruits with Phytophthora infestans (\%) & 12 & $0.80 \pm 0.21^{b}$ & $0.73 \pm 0.26^{b}$ & $3.61 \pm 0.56^{a}$ & $F_{2,9}^{, 9}=19.01$ & $<0.001$ \\
\hline
\end{tabular}

$n$, Number of replicates for each characteristic; IPM, integrated pest management; ANOvA, analysis of variance.

Means followed by the same superscript letter in a row do not differ significantly by the Scott-Knott multiple range test. 


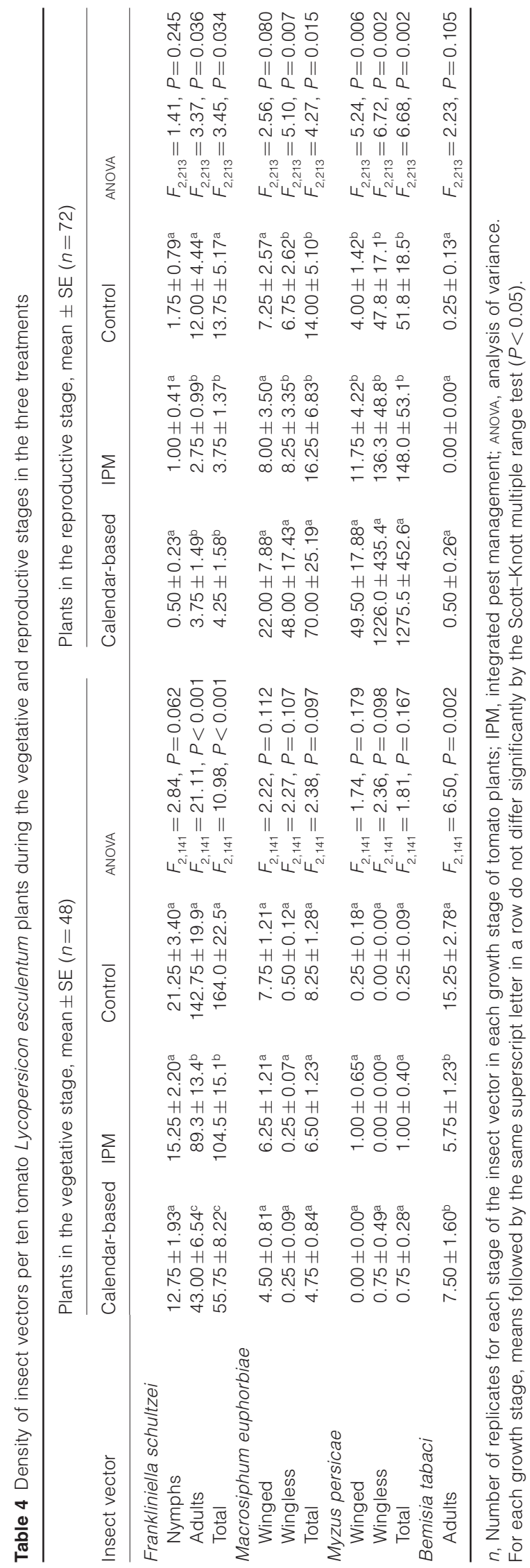

parasitoids (Miranda et al., 2005). Populations of other predators and parasitoids found in the tomato crop were similar among the three treatments (Table 5).

\section{Discussion}

Although plants and flowers were lost during the crop cycle, the fruit component influenced more the fluctuation of yield losses. These results agree with previous studies, indicating higher noncumulative losses during the reproductive stage of tomato (Picanço et al., 1997, 1998; Paula et al., 1998). For this reason, the most critical component of production was the fruit.

The larval behaviour of $N$. elegantalis explains the high fruit damage (15.54\%) caused by this pest in this trial: the neonates penetrate quickly into the fruit after emergence, and are thus protected from insecticide and natural enemies (Eiras \& Blackmer, 2003). Munõz et al. (1991) and Plaza et al. (1992) measured parasitism rates of just $2 \%$ in this species, and Barbosa \& França (1980) observed 90\% of production losses due to N. elegantalis. This fruit borer also contributed to higher incidence of the bacterium E. carotovora. The occurrence of E. carotovora was reported to be associated with hot and rainy seasons similar to that experienced in the present study and attack of insect borers (Lopes \& Quezado-Soares, 2000).

The occurrence of tospoviruses only in the fruits was result of transmission by viruliferous $F$. schultzei on flowers (Pavan et al., 1996). These diseases occur mainly during the hot season, due to the proliferation of $F$. schultzei (Tokeshi \& Carvalho, 1980). Weather conditions associated with this experiment also explain the incidence of A. solani and $P$. infestans. Alternaria solani attacks the tomato crop during both hot and cold seasons, but is more severe during the fruiting stage and hot seasons due to higher temperatures (Rotem, 1994; Vale et al., 2000). The fungus $P$. infestans is frequent during cold and humid periods, but disease may also occur during hot periods of the year if there is abrupt reduction of night temperature accompanied by heavy rains (Vale et al., 2000).

Our results revealed that IPM efficiently controlled pests and reduced pesticide use. Imenes et al. (1992) and Trumble \& Alvarado-Rodriguez (1993) verified larger net profits using IPM practices. In addition to the economic outcome, IPM provides ecological and social advantages. Insecticide applications may decrease populations of natural enemies (Pacora, 1982; Raga et al., 1990; Miranda et al., 2005) and affect human health, either by contamination of applicators and fruits or by contamination of water and soil (Moreira \& Oliveira, 1997).

In general, IPM had a positive impact on populations of natural enemies, although the high number of insecticide applications to control fruit borers during the reproductive stage negatively affected populations of Araneidae, Formicidae, Anthicidae and Phaleothripidae. In this crop stage, the occurrence of fruit borers required the same number of insecticide applications as the calendar-based system.

IPM favoured predators, such as Coccinellids, which have a large impact on population densities of aphids (Hagen \& Van den Bosch, 1968; Nakata, 1995; Semyanov, 1997). Coccinellid densities were negatively correlated with densities of the aphids $M$. persicae and M. euphorbiae. Miranda 


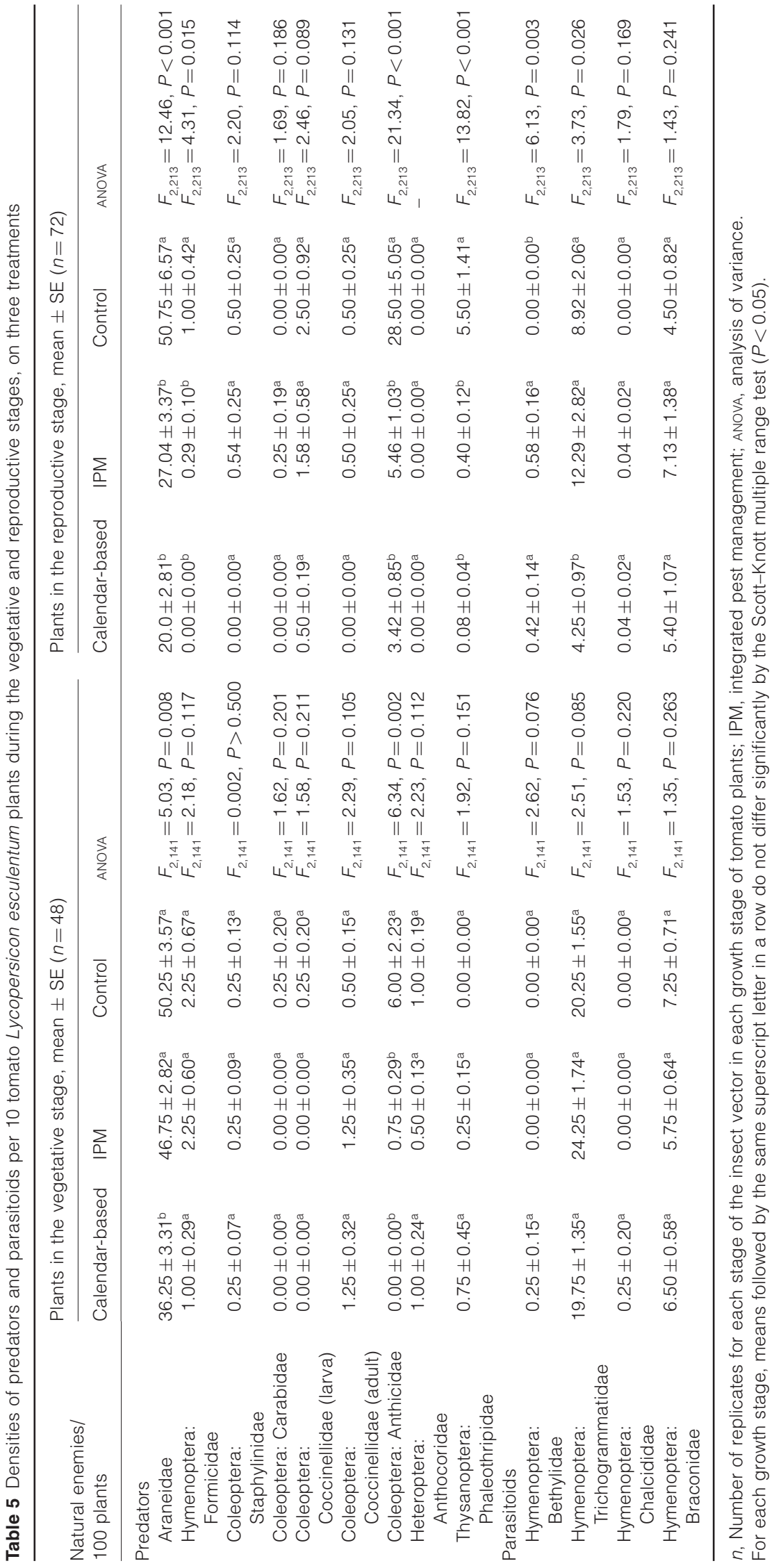


et al. (1998) obtained similar results, observing negative correlations between the density of $C$. sanguinea adults and the densities of $M$. euphorbiae and $M$. persicae. The aphids $M$. euphorbiae and $M$. persicae were managed with pirimicarb, an aphicide with a recognized low toxicity to Coccinelidae (Lecrone \& Smilowitz, 1980; Gusmão et al., 2000; James, 2003). It is unlikely that pirimicarb caused disruption of biological control provided by $C$. sanguinea because it was sprayed only once in the calendar-based plots, comprising $3.0 \%$ of the total number of applications. Therefore, the high densities of aphids in the calendar-based system may be associated with the high number of parathion-methyl and abamectin applications to manage $F$. schultzei and fruit borers, respectively. These insecticides may have negatively impacted $C$. sanguinea because tolerance of Coccinelidae to abamectin and parathion-methyl has been reported to be low in laboratory and field trials. Abamectin was toxic to Harmonia axyridis (Pallas) (James, 2003; Youn et al., 2003) and Stethorus punctum picipes (Casey) (James, 2003). Cycloneda sanguinea and Eriopis connexa (Germar) showed low tolerance to parathion-methyl in tomato leaf dip assays (Gusmão et al., 2000). Harmonia axyridis was less tolerant than Aphis gossypi (Glover) (Aphididae) to the organophosphate acephate, which could explain resurgence of A. gossypi (Glover) (Aphididae) in areas where this insecticide was used (Ito et al., 2005). The calendar-based system had also a negative influence on the population of Trichogrammatidae, which parasitizes eggs of $N$. elegantalis and has been identified as potential candidate for augmented biological control (Parra \& Zucchi, 2004).

In conclusion, in the present study, we have demonstrated that tomato yield is directly related to losses caused during the reproductive stage and that fruit is the production component most susceptible to losses. For this reason, cultivation and IPM practices should prioritize the reduction of the effects of loss factors over the fruit component, particularly fruit borers that can directly injure fruits and also increase the incidence of disease. The application of IPM in tomato reduced the number of insecticide applications and increased the population of natural enemies in this trial. The high number of insecticide applications in the calendar-based system reduced Trichogrammatidae, which can be important for control of the fruit borer $N$. elegantalis.

\section{Acknowledgements}

We thank the Brazilian Ministry of Education (CAPES Foundation), National Council of Scientific and Technological Development (CNPq), and Minas Gerais State Foundation of Research Aid (FAPEMIG) for financial support, and the taxonomists: Professor Roberto Antônio Zucchi (ESALQ/USP) for the identification of Trichogramma spp., Professor Celso Oliveira Azevedo (UFES/ES) for the identification of Bethylidae, Professor Angélica Maria Penteado-Dias for the identification of Braconidae, Dr Ayr de Moura Bello from Rio de Janeiro, for the identification of Coleoptera: Anthicidae and Professor Paulo Sérgio Fiúza Ferreira (UFV/MG-BR) for the identification of the parasitoids and species of the predatory bugs (Heteroptera: Anthocoridae). We also thank Dr Deanna Namuth and Dr Lance J. Meinke for critically reading a draft of the manuscript, and all the undergraduate and graduate students from the Animal Biology Department who helped to successfully complete this trial by assisting during plant cultivation, insect scouting, pesticide sprayings, and fruit harvesting.

\section{References}

Barbosa, S. \& França, F.H. (1980) As pragas do tomateiro e seu controle. Informe Agropecuário, 6, 37-39.

Barrigossi, J.A.F., Lopes, N.F. \& Chandler, L. (1988) Resposta fisiológica do feijoeiro (Phaseolus vulgaris L.) ao forate e suas consequências entomológicas. II. Crescimento, morfologia, partição de assimilados e produção de matéria seca das plantas. Revista Ceres, 35, 341-354.

Calil, A.C.P., Chandler, L., Galvão, J.D., Casali, V.W.D. \& Nogueira, S.B. (1985) Tabela de vida das culturas para o feijoeiro (Phaseolus vulgaris L.) com ênfase nas pragas e seus danos em três plantios no período das chuvas. Revista Ceres, 32, 186-226.

Chandler, L. (1984) Crop life table studies of the pests of beans (Phaseolus vulgaris L.) at Goiânia-GO. Revista Ceres, 31, 284-298.

Cho, K., Mitchell, W.C., Mau, R.F.L. \& Sakimura, K. (1987) Epidemiology of tomato spotted wilt virus disease on crisphead lettuce in Hawaii. Plant Disease, 71, 505-508.

Costa, M.C., Della Lucia, T.M.C., Vilela, E.F., Chandler, L. \& Sediyama, T. (1993) Tabela de vida de cultivares de soja e variação sazonal da entomofauna. Pesquisa Agropecuária Brasileira, 28, 1233-1245.

Della Lucia, T.M.C., Chandler, L., Casali, V.W.D., Galvão, J.D., Costa, L.M. \& Freire, J.A.H. (1984) Aplicação da tabela de vida das culturas às pragas de feijoeiro Phaseolus vulgaris L., em quatro níveis de adubação. Revista Ceres, 31, 444-463.

Dent, D. (2000) Insect Pest Management, 2nd edn. CAB International, U.K.

Eiras, A.E. \& Blackmer, J.L. (2003) Eclosion time and larval behaviour of the tomato fruit borer, Neoleucinodes elegantalis (Guenée) (Lepidoptera: Crambidae). Scientia Agricola, 60, 195-197.

Fajardo, T.M.U., Ávila, A.C. \& Resende, R.O. (2000) Doenças causadas por vírus em tomate. Controle de Doenças de Plantas: Hortaliças (ed. by L. Zambolim, F. X .R. Vale and H. Costa), pp. 843-878. Suprema Gráfica e Editora Ltda, Brazil.

FAO (2002) Production Yearbook, 2000, Vol. 54. FAO; Italy.

Filgueira, F.A.R. (2003) Novo Manual de Olericultura: Agrotecnologia Moderna na Produção e Comercialização de Hortaliças. Editora UFV; Brazil.

Guedes, R.N.C., Picanço, M.C., Matioli, A.L. \& Rocha, D.M. (1994) Efeito de inseticidas e sistemas de condução do tomateiro no controle de Tuta Absoluta (Meyrick) (Lepidoptera: Gelechiidae). Anais da Sociedade Entomológica do Brasil, 23, 321-325.

Gusmão, M.R., Picanço, M., Leite, G.L.D. \& Moura, M.F. (2000) Seletividade de inseticidas a predadores de pulgões. Horticultura Brasileira, 18, 130-133.

Hagen, K.S. \& Van den Bosch, R. (1968) Impact of pathogens, parasites, and predators on aphids. Annual Review of Entomology, 13, 325-384. Imenes, S.D.L., Campos, T.B., Takematsu, A.P., Bergmann, E.C. \& Silva, M.A.D. (1992) Efeito do manejo integrado na população de pragas e inimigos naturais na produção de tomate estaqueado. Arquivo do Instituto Biológico, 59, 1-7. 
Ito, K., Furukawa, K. \& Okubo, T. (2005) Conservation biological control of aphids in potato fields with reduced use of insecticides in Hokkaido, Japan. Japanese Journal of Applied Entomology and Zoology, 49, 11-22.

James, D.G. (2003) Pesticide susceptibility of two coccinellids (Stethorus punctum picipes and Harmonia axyridis) important in biological control of mites and aphids in Washington hops. Biocontrol Science and Technology, 13, 253-259.

Lecrone, S. \& Smilowitz, Z. (1980) Selective toxicity of pirimicarb, carbaryl and methamidophos to green peach aphid (Myzus persicae) (Sulzer), Coleomegilla Maculata lengi (Timberlake) and Chrysopa aculata Say. Environmental Entomology, 9, 752-755.

Leite, D., Bresciani, A.F., Groppo, A.G., Pazini, W.C. \& Gravena, S. (1995) Comparação de estratégias de manejo de pragas na cultura do tomate estaqueado. Anais da Sociedade Entomológica do Brasil, 24, 27-32.

Leite, G.L.D., Picanço, M.C., Madeira, N.R. \& Zanuncio, J.C. (1996) Efeito de inseticidas sistêmicos aplicados no solo na produção do feijoeiro. Bragantia, 55, 279-287.

Lopes, C.A. \& Quezado-Soares, A.M. (2000) Doenças causadas por bactérias em tomate. Controle de Doenças de Plantas: Hortaliças (ed. by L. Zambolim, F. X. R. Vale and H. Costa), pp. 757-800. Suprema Gráfica e Editora Ltda, Brazil.

Miranda, M.M.M., Picanço, M., Matioli, A.L. \& Pallini Filho, A. (1998) Distribuição na planta e controle biológico natural de pulgões (Homoptera: Aphididae) em tomateiros. Revista Brasileira de Entomologia, 42, 13-16.

Miranda, M.M.M., Picanço, M., Zanuncio, J.C., Bacci, L. \& Silva. E.M. (2005) Impact of integrated pest management on the population of leafminers, fruit borers, and natural enemies in tomato. Ciência Rural, 35, 204-208.

Moreira, L.F. \& Oliveira, J.S. (1997) Análise de resíduos de metamidofós em frutos de tomate, água e solo da região agrícola de Viçosa-MG. Revista Ceres, 44, 161-168.

Morris, R.F. (1963) Predictive population equations based on key factors. Memoirs of the Entomological Society of Canada, 32, $16-21$.

Munõz, L.E., Serrano, P.A., Pulido, J.I. \& de La Cruz, J.L. (1991) Ciclo de vida, habitos y enemigos naturales de Neoleucinodes elegantalis (Guenee, 1854) (Lepidoptera: Pyralidae), pasador del fruto del lulo Solanum quitoense Lam en el Valle Del Cauca. Acta Agronomica, 41, 99-104.

Nakata, T. (1995) Population fluctuations of aphids and their natural enemies on potato in Hokkaido. Japanese Journal of Applied Entomology and Zoology, 30, 129-138.

Pacora, R.J.F. (1982) Parasitismo observado sobre dos insectos plaga en el cultivo de la papa del Valle Chillón. Revista Peruana de Entomologia, 21, 125-125.

Parra, J.R.P. \& Zucchi, R.A. (2004) Trichogramma in Brazil: feasibility of use after twenty years of research. Neotropical Entomology, 33, 271-281.

Paula, S.V., Picanço, M.C., Fontes, P.C.R. \& Vilela, E.F. (1998) Fatores de perdas no tomateiro com a adoção de nível de controle e de faixas circundantes. Revista Agro-Ciência, 14, 262-273.

Pavan, M.A., Costa, A.S., Kurozawa, C. \& Soler, J.M.P. (1996) Localized infection on tomato fruits caused by tospovirus. Summa Phytopathologica, 22, 14-19.

Pedigo, L.P. (2002) Entomology and Pest Management. Macmillan, New York, New York.

Picanço, M. (1992) Entomofauna e danos das pragas associadas à cultura de ervilha (Pisum sativum L.), em quatro épocas de plantio e 54 variedades. DS Thesis, Universidade Federal de Viçosa.
Picanço, M.C., Faleiro, F.G., Pallini Filho, A. \& Matioli, A.L. (1997) Perdas na produtividade do tomateiro em sistemas alternativos de controle fitossanitário. Horticultura Brasileira, 15, 88-91.

Picanço, M.C., Guedes, R.N.C., Leite, G.L.D., Fontes, P.C.F. \& Silva, E.A. (1995) Incidência de Tuta absoluta em tomateiro sob diferentes sistemas de tutoramento e de controle químico. Horticultura Brasileira, 13, 180-183.

Picanço, M.C., Leite, G.L.D., Guedes, R.N.C. \& Silva, E.A. (1998) Yield loss in trellised tomato affected by insecticidal sprays and plant spacing. Crop Protection, 17, 447-452.

Picanço, M. \& Marquini, F. (1999) Manejo integrado de pragas de hortaliças em ambiente protegido. Informe Agropecuário, 20, 126-133.

Picanço, M.C., Silva, F.M. \& Galvan, T.L. (2001) Manejo integrado de pragas de hortaliças. Manejo de Pragas Em Cultivos Irrigados Sob Pivô Central (ed. by L. Zambolim.), pp. 427-480. Suprema Gráfica e Editora Ltda, Brazil.

Plaza, A.S., Leon, E.M., Fonseca, J.P. \& Cruz, L.J. (1992) Biologia, habitos y enemigos naturales de Neoleucinodes elegantalis (Guenée, 1854). Revista Colombiana de Entomologia, 88, 32-37 (1992).

Podoler, H. \& Rogers, D. (1975) A new method for the identification of key factors from life-table data. Journal of Animal Ecology, 44, $85-114$.

Raga, A., Gravena, S., Bortoli, S.A., Arai, J. \& Wassano, G.N. (1990) Amostragem de insetos e atividade de artrópodos predadores na cultura do tomateiro de crescimento determinado. Anais da Sociedade Entomológica do Brasil, 19, 253-271.

Resende, R.A. \& Cupertino, F.P. (1996) Doenças causadas por vírus em tomateiro. Informe Agropecuário, 18, 19-27.

Resende, M., Curi, N. \& Santana, D.P. (1988) Pedologia e Fertilidade dos Solos: Interações e Aplicações. MEC, Brazil.

Ribeiro Júnior, J.I. (2001) Análises Estatísticas No SAEG 2001 User's Guide, Version 8. UFV, Brazil.

Rotem, J. (1994) The Genus Alternaria: Biology, Epidemiology and Pathogenicity. APS Press, St Paul, Minnesota.

Semyanov, V.P. (1997) Some results and perspectives of the use of tropical coccinellids (Coleoptera, Coccinellidae) against aphids in greenhouses. Entomological Review, 76, 467-472.

Sikora, E.J., Kemble, J.M., Zehnder, G.W., Goodman, W.R., Andrianifahanana, M., Bauske, E.M. \& Murphy, J.F. (2002) Using on-farm demonstrations to promote integrated pest management practices in tomato production. HortTechnology, 12, 485-488.

SPSS, SigmaPlot (2000) User's Guide. SPSS Inc., Chicago, Illinois.

Tokeshi, H. \& Carvalho, P.C.T. (1980) Doenças do tomateiro - Lycopersicum esculentum Mill. Manual de Fitopatologia: Doenças das Plantas Cultivadas (ed. by F. Galli), pp. 511-552. Agronômica Ceres, Brazil.

Trumble, J.T. \& Alvarado-Rodriguez, B. (1993) Development and economic evaluation of an IPM program for fresh market tomato production in México. Agriculture Ecosystems and Environment, 43, 267-284.

USDA (1975) Soil Taxonomy. A Basic System of Soil Classification for Making and Interpreting Soil Surveys. USDA, Washington, District of Columbia.

Vale, F.X.R., Zambolim, L., Paul, P.A. \& Costa, H. (2000) Doenças causadas por fungos em tomate. Controle de Doenças de Plantas: Hortaliças (ed. by L. Zambolim, F. X. R. Vale and H. Costa), pp. 699-756. Suprema Gráfica e Editora Ltda, Brazil.

Youn, Y.N., Seo, M.J., Shin, J.G., Jang, C. \& Y.M. (2003) Toxicity of greenhouse pesticides to multicolored Asian lady beetles, Harmonia axyridis (Coleoptera: Coccinellidae). Biological Control, 28, 164-170.

Accepted 18 May 2007

First published online 20 August 2007 